\title{
UMH 1422 and UMH 1415: Two Fresh- market Tomato Breeding Lines Resistant to Tomato Mosaic Virus and Tomato Spotted Wilt Virus
}

\author{
Santiago García-Martínez, Adrián Grau, Aranzazu Alonso, \\ Fernando Rubio, Manuel Valero, and Juan J. Ruiz ${ }^{1}$ \\ Department of Applied Biology, Universidad Miguel Hernández, Escuela \\ Politécnica Superior de Orihuela, Carretera de Beniel, km. 3,2, 03312, \\ Orihuela, Spain
}

Additional index words. ToMV, TSWV, Tm-2 ${ }^{\mathrm{a}}, \mathrm{Sw}-5$

The incidence of several viral diseases such as those caused by Tomato mosaic virus (ToMV) and Tomato spotted wilt virus (TSWV) makes tomato landrace cultivation practically nonviable in many areas of southeastern Spain, especially in open-field conditions (Ruiz et al., 2005). 'De la Pera' and 'Muchamiel' are two tomato landraces that are very appreciated as a result of their organoleptic fruit quality. The Miguel Hernández University breeding program for the introgression of virus resistance into Spanish landraces has already resulted in the release of two breeding lines, UMH 1200 and UMH 1203, both homozygous for $T m-2^{a}, T y-1$, and $S w-5$ genes (García-Martínez et al., 2011, 2012). These breeding lines allow farmers to obtain acceptable harvest under intense virus infection conditions. However, when compared with the original landraces under low virus incidence conditions, important yield decreases were obtained for these breeding lines, ranging between $50 \%$ and $75 \%$ decrease for UMH 1200 and between $40 \%$ and $50 \%$ for UMH 1203 (García-Martínez et al., 2011, 2012). These results are the result of the introgressed genes and/or to the linkage drag, as previously reported in processing tomatoes (Tanksley et al., 1998) and in fresh tomato (Rubio et al., 2012), although the yield problems are mainly the result of the introgression of the $T y-1$ gene for Tomato yellow curl virus (TYLCV) resistance. For this reason, we have developed the breeding lines UMH 1422 and UMH 1415 without TYLCV resistance. The two lines are useful for tomato cropping in the spring to summer growing cycle, when the incidence of the viruses caused by TYLCV is less intense. Both lines have medium-sized fruits (70 to $90 \mathrm{~g}$ ) with a bell shape and green shoulders

\footnotetext{
Received for publication 28 Aug. 2014. Accepted for publication 5 Oct. 2014.

This work was partially supported by the Spanish MICINN through projects AGL2005-03946, AGL2008-03822, and AGL2011-26957.

${ }^{1}$ To whom reprint requests should be addressed; e-mail juanj.ruiz@umh.es.
}

resistance to ToMV, TSWV, and TYLCV, respectively. Using marker-assisted selection for the three virus resistance genes, nine backcross generations to the De la Pera cultivar were performed. Several trials under different infection conditions (mechanical inoculation for ToMV and natural infection for TYLCV and TSWV) were carried out to control the presence of the resistance alleles in the backcross generations and the effectiveness of the molecular markers. In addition, a high selection pressure for 'De la Pera' characteristics (bell shape, green shoulder, low sensitivity to blossom-end rot) and good agronomic behavior were applied during all backcross generations. After the selfing of a single triple heterozygous plant from a $\mathrm{BC}_{9} \mathrm{~F}_{9}$ family followed by two additional generations of selfing and selection, the pure breeding lines UMH 1422, homozygous only for $T m-2^{a}$, and UMH 1415, homozygous only for $T m-2^{a}$ and $S w-5$, were selected using molecular markers and multiplied by selfpollination in a greenhouse under controlled conditions.

\section{Description and Performance}

UMH 1422 is homozygous for $\mathrm{Tm}-2^{a}$ (ToMV resistance gene), whereas UMH 1415 is homozygous for $T m-2^{a}$ and $S w-5$ (ToMV and TSWV resistance genes, respectively). The lines have indeterminate growth with intermediate foliage density. From 2009 to 2011 we cultivated UMH 1422, UMH 1415 , and the recurrent cultivar P21 under different conditions (open field, greenhouse, and mesh-covered net house) in the spring to summer crop cycle, the most widely used growing cycle in the traditional area of ' $\mathrm{De}$ la Pera' tomato cultivation. UMH 1422 showed

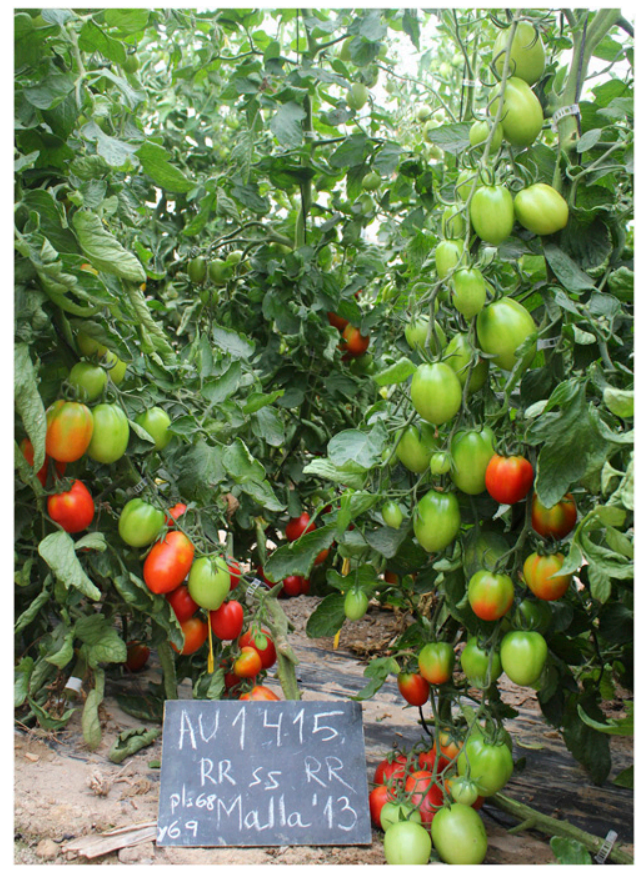

Fig. 1. Fruits of UMH 1415. 
Table 1. Yield traits, titratable acidity (TA), and soluble solids concentration (SSC) of the breeding lines UMH 1422, UMH 1415, and 'De la Pera' landrace (accession P21) grown in the open field, greenhouse, and mesh-covered net house in the spring to summer crop cycle.

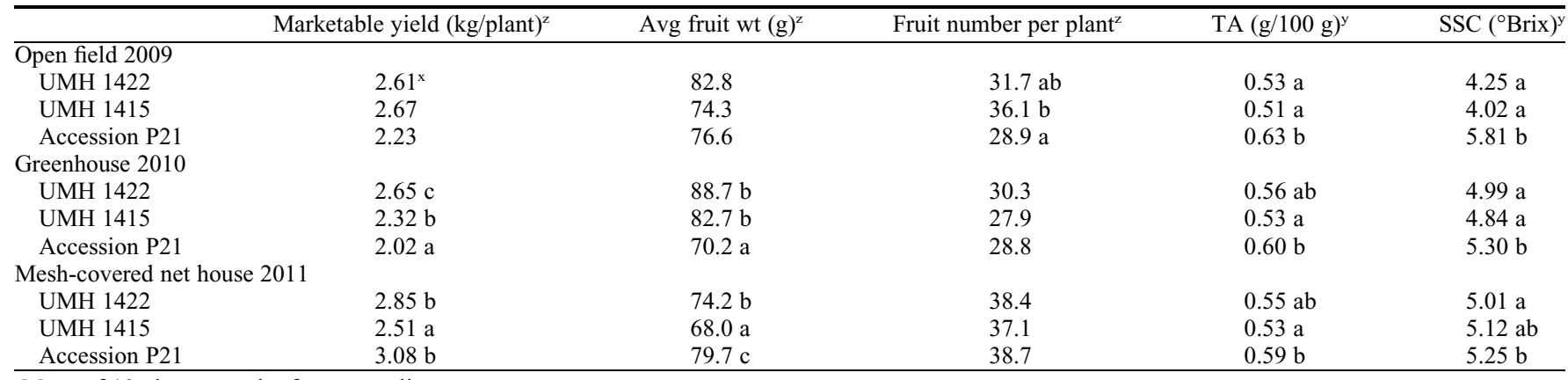

${ }^{\mathrm{z}}$ Mean of 10 plants per plot for two replicates.

${ }^{\mathrm{y}}$ Mean of 10 fruits per plot for two replicates.

${ }^{\mathrm{x}}$ Mean values in a column followed by a different letter are significantly different according to Duncan's multiple range test $(P<0.05)$.

Table 2. Sensory analysis for the breeding lines UMH 1422 and UMH 1415 and 'De la Pera' landrace (accession P21) grown in the mesh-covered net house in 2011 in the spring to summer crop cycle. ${ }^{\mathrm{z}}$

\begin{tabular}{lcccc}
\hline Line cultivar & External appearance & Flavor & Texture & Overall acceptability \\
\hline UMH 1422 & $2.7 \mathrm{~b}^{\mathrm{x}}$ & 2.2 & 2.6 & 2.3 \\
UMH 1415 & $2.3 \mathrm{a}$ & 2.5 & 2.5 & 2.4 \\
Accession P21 & $2.4 \mathrm{a}$ & 2.4 & 2.5 & 2.4 \\
\hline
\end{tabular}

${ }^{\mathrm{z}}$ For sensory analysis, fruits were washed and cut into wedges. The tests were conducted according to the ranking method (Gould, 1983).

${ }^{y}$ Each value is the mean of the scores of 42 untrained tasters on a 1 (bad) to 3 (good) scale.

${ }^{x}$ Each value in a column followed by a different letter are significantly different according to Duncan's multiple range test $(P<0.05)$.

similar or better agronomic characteristics than the original cultivar P21 (Table 1). UMH 1415 yielded similarly or lower than UMH 1422 , whereas the differences with the cultivar P21 depended on the trial. A significant decrease in both titratable acidity and soluble solid content of fruit was found for the breeding lines compared with the landrace, in the three trials, being less marked in the trial performed under the mesh-covered net house in 2011 (Table 1). However, tomato tasting panels composed of untrained tasters found no significant differences between the breeding lines and P21 line for flavor, texture, and overall acceptability, although the panels detected differences for external appearance (Table 2). UMH 1422 received higher scores for external appearance than UMH 1415 and P21, whereas UMH 1415 and P21 showed no significant differences for this trait. Results of sensory analysis indicated similar organoleptic values of the breeding lines and the traditional cultivar, suggesting that the introgressed resistance genes have not reduced significantly fruit organoleptic quality.

\section{Use}

UMH 1422 has genetic resistance to ToMV, whereas UMH 1415 has genetic resistance to ToMV and TSWV, viruses that usually affect tomato landrace cultivation in southeastern Spain, especially in open-field conditions. These breeding lines could be useful for tomato cultivation in the spring to summer growing cycle, when the incidence of the diseases caused by TYLCV is less intense, as a result of the low population levels of the whitefly vector Bemisia tabaci (Genn.). The reduced linkage drag in these lines is not only evident from the consumer acceptability similar to that of the recurrent landrace, but also from the no decrease in yield. As previous releases produced by our breeding program, UMH 1422 and UMH 1415 are being licensed to a private company to develop $F_{1}$ hybrids by crossing them with other landraces and breeding lines to use the genetic resistance in a heterozygous state. In addition, UMH 1422 and UMH 1415 have been incorporated into breeding programs to facilitate the introgression of the resistance genes into several other tomato Spanish landraces.

\section{Availability}

Small trial seed samples of the UMH 1422 and UMH 1415 breeding lines are available for research purposes (contact the authors).

\section{Literature Cited}

García-Martínez, S., A. Grau, A. Alonso, F. Rubio, M. Valero, and J.J. Ruiz. 2011. UMH 1200, a breeding line within the Muchamiel tomato type resistant to three viruses. HortScience 46:1054-1055.

García-Martínez, S., A. Grau, A. Alonso, F. Rubio, M. Valero, and J.J. Ruiz. 2012. UMH 1203, a multiple virus-resistant fresh-market tomato breeding line for open-field conditions. HortScience 47:1-2.

Gould, W.A. 1983. Tomato production, processing and quality evaluation. 2nd Ed. AVI Publ., Westport, CT.

Pérez de Castro, A., J.M. Blanca, M.J. Díez, and F. Nuez. 2007. Identification of a CAPS marker tightly linked to the Tomato yellow leaf curl disease resistance gene $T y-1$ in tomato. Eur. J. Plant Pathol. 117:347-356.

Rubio, F., S. García-Martínez, A. Alonso, A. Grau, M. Valero, and J.J. Ruiz. 2012. Introgressing resistance genes into traditional tomato varieties: Effects on yield and quality. Acta Hort. 935:29-33.

Ruiz, J.J., S. García-Martínez, B. Picó, M. Gao, and C.F. Quiros. 2005. Genetic variability and relationship of closely related Spanish traditional cultivars of tomato as detected by SRAP and SSR markers. J. Amer. Soc. Hort. Sci. 130:88-94.

Tanksley, S.D., D. Bernachi, T. BeckBunn, D. Emmatty, Y. Eshed, S. Inai, J. Lopez, V. Petiard, H. Sayama, J. Uhlig, and D. Zamir. 1998. Yield and quality evaluations on a pair of processing tomato lines nearly isogenic for the $T m 2^{a}$ gene for resistance to the Tobacco mosaic virus. Euphytica 99:77-83. 